\title{
Influence of carbon source on the expression of Cochliobolus carbonum xylan-degrading enzyme genes
}

\author{
Nyerhovwo J. Tonukari ${ }^{\Psi, *}$, John S. Scott-Craig and Jonathan D. Walton \\ Department of Energy Plant Research Laboratory, Michigan State University, East Lansing, Michigan 48824.
}

Accepted 18 November 2002

The expression of four Cochliobolus carbonum endo-1,4- $\beta$-xylanase genes (XYL1, XYL2, XYL3, XYL4), and an exo-1,4- $\beta$-xylosidase gene (XYP1) was studied following the growth of the fungus in minimal medium containing glucose, sucrose, xylose, xylan, pectin, or cellulose. The XYL1 and XYL2 genes were expressed only when the culture medium contained xylan or cellulose. Both $X Y L 3$ and $X Y L 4$ are induced by xylose and xylan, and XYP1 expression is induced by xylose, xylan, pectin and cellulose. None of these genes is expressed in glucose or sucrose media. The differential expression of these enzymes may provide means for the fungus to adapt to different conditions.

Key words: Cell wall degrading enzymes, Cochliobolus carbonum, xylan, xylanase.

\section{INTRODUCTION}

The role of fungal-secreted extracellular enzymes in diseases has been postulated to include penetration of the plant cell walls, release of nutrients that can be assimilated for growth and the elicitation of defense responses (Walton, 1994). Cochliobolus carbonum, an ascomycetous pathogen of maize, penetrates into and ramifies through intact leaves and in the process obtains nutrients for growth from the plant cell cytoplasm and walls. C. carbonum synthesizes numerous extracellular enzymes, such as pectinases, xylanases, glucanases and proteases, which can degrade the polysaccharides of the maize cell wall. The disease caused by this fungus, Northern leaf spot of corn, is characterized by extensive necrotization of susceptible maize tissues.

The full expression of these cell wall degrading enzymes (CWDEs) by fungi depends on mechanisms that are associated with the glucose regulation pathway. In many organisms, glucose represses genes whose products are used to metabolize other carbon sources. Work in yeast and filamentous fungi have revealed a mechanism for glucose repression in eukaryotes that is

$\Psi$ Present address: International Livestock Research Institute, P.O. Box 30709, Nairobi, Kenya.

${ }^{*}$ Corresponding author; tel: 254-2-630743, fax: 254-2-631499, e-mail: J.TONUKARI@CGIAR.ORG

Abbreviation: CWDE(s); Cell Wall Degrading Enzyme(s). different from that found in bacteria (Ronne, 1995). We reported previously that the $C$. carbonum SNF1 gene is required for the expression of many CWDEs (Tonukari et al., 2000). Mutation of SNF1 in the fungus leads to varying levels of repression of CWDE genes, reduced growth on complex polymers such as xylan and pectin, and also reduced virulence on its host, maize. Here we studied the expression of xylan-degrading genes following the growth of the fungus in minimal medium containing different carbon sources.

\section{RESULTS AND DISCUSSION}

Northern hybridization was employed to determine the effect of glucose on the expression of $C$. carbonum CWDE genes. Four endo-1,4- $\beta$-xylanase genes ( $X Y L 1$, $X Y L 2, X Y L 3, X Y L 4$ ) (Apel et al., 1993; Apel-Birkhold and Walton, 1996; J.S. Scott-Craig, Michigan State University, unpublished results), and an exo-1,4- $\beta$ xylosidase gene (XYP1) (Ransom and Walton, 1997; Wegener et al., 1999) has been cloned from $C$. carbonum. The expression of these genes was initially studied following growth of the fungus in minimal medium containing glucose or xylan. Expression of all five genes was detected only when the culture medium contained xylan. In glucose medium, the xylandegrading enzyme genes were repressed (Figure 1A). 
The expression of the four endo-1,4- $\beta$-xylanase and exo-1,4- $\beta$-xylosidase genes was also studied during growth of the fungus in minimal media containing sucrose, xylose, xylan, pectin, or cellulose as the sole carbon source. Northern hybridization studies show that the $X Y L 1$ and $X Y L 2$ genes were expressed only when the culture medium contained xylan or cellulose. While $X Y L 3$ and $X Y L 4$ expression was detected only when xylose or xylan was in the medium. XYP1 expression was induced by xylose, xylan, pectin and cellulose. Like glucose, the presence of sucrose in the medium suppressed the expression of all five genes (Figure 1B).

A.

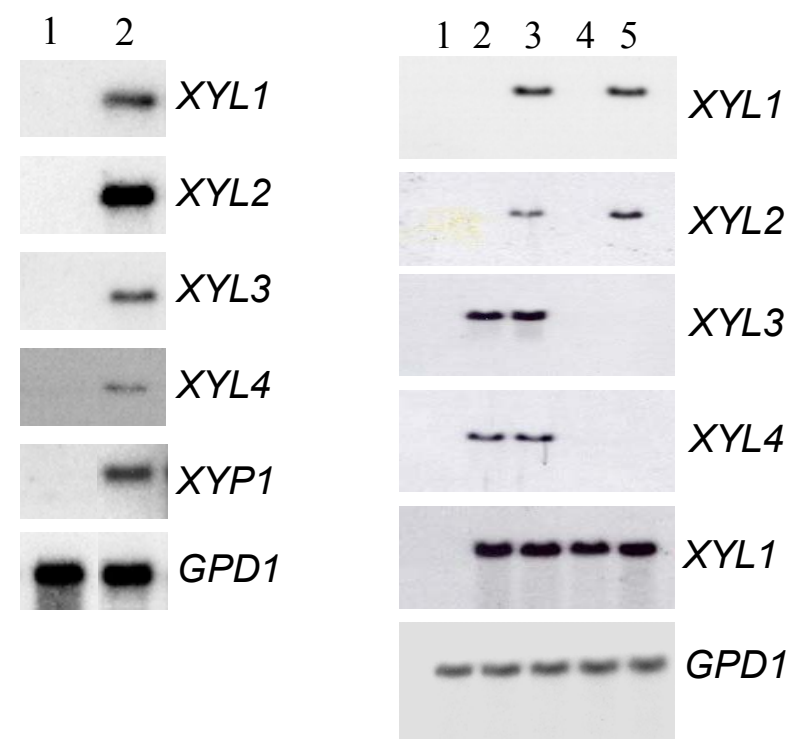

Figure 1. Expression of $C$. carbonum xylan-degrading enzymes. The wild-type race 1 strain of $C$. carbonum (367-2A) was grown in liquid media containing mineral salts, $0.2 \%$ yeast extract, and trace elements (Van Hoof et al. 1991) with $2 \%$ carbon source. Four fungal agar plugs (each about $5 \mathrm{~mm}^{2}$ ) were inoculated into a $1 \mathrm{~L}$ Erlenmeyer flask containing $125 \mathrm{ml}$ of medium and grown in still culture for seven days at room temperature. Mycelial mats were washed briefly in distilled water, frozen, and lyophilized. Total RNA was extracted from lyophilized mats (Pitkin et al. 1996; Apel et al. 1993) and northern blot analysis conducted as described by Apel-Birkhold and Walton 1996. A. Effect of glucose on $C$. carbonum xylan-degrading enzymes: glucose (lane 1) or xylan (lane 2) were used as sole carbon source. B. Effect of other carbon sources on $C$. carbonum xylan-degrading enzymes: sucrose (lane 1), xylose (lane 2), xylan (lane 3), pectin (lane 4), or cellulose (lane 5) were used for fungal growth. The Cochliobolus heterostophus GPD1 gene, encoding glyceraldehyde-3-phosphate dehydrogenase (Van Wert and Yoder 1992), was used as a reference.
The repression of xylanases and other CWDEs by preferred carbon sources such as glucose (Asymeric et al., 1988) is an efficient energy-conserving mechanism because the activity of enzymes that degrade xylan and other polysaccharides may not be required when glucose is abundant in the growth medium. However, genes that are important for promoting host colonization by pathogens must be expressed at some stage during infection (Hensel and Holden, 1996). Many of these genes are only activated in the appropriate environment, often in response to signals from the host, and therefore may only expressed when required. This study revealed that the expression of the various $C$. carbonum xylandegrading enzyme genes is substrate-induced, though not necessarily in the same manner in vitro.

The biosynthesis of some xylanases may also be induced in the presence of other polysaccharides such as pectin and cellulose, in addition to xylan, as was observed in our experiments. In addition, the cell wall degradation product from one xylanase or other CWDEs may induce expression of other xylanase as well as other CWDE genes. We found that xylose, a product of xylan degradation, can also induce the expression of three of the five xylan-degrading enzyme genes $(X Y L 3$, $X Y L 4$ and $X Y P 1)$ in this investigation. Polygalacturonase, pectate lyase and pectin lyase activities are also induced in media supplemented with galactose or galacturonic acid (Crotti et al., 1998; ScottCraig et al., 1990, 1998). Kolattukudy et al. (1995) also reported that cutinase carried by spores of virulent pathogens, upon contact with plant surface, release small amounts of cutin monomers that trigger cutinase gene expression. Furthermore, Trichoderma reesei $X Y N 2$ (xylanase) gene is induced in the presence of xylose (in addition to xylan), and like the xylanases in this study, it is virtually silenced in the presence of glucose (Zeilinger et al., 1996; Mach et al. 1996). The differential expression of these functionally redundant xylanases may serve to ensure that enzymes capable of degrading xylan are present under the various conditions encountered by the fungus during growth in its host plant. This may provide means to adapt to different conditions, and is indicative of processes with vital importance to an organism.

\section{ACKNOWLEDGEMENTS}

This research was supported by the U.S. Department of Energy, Division of Energy Biosciences.

\section{REFERENCES}

Apel PC, Panaccione DG, Holden FR, Walton JD (1993). Cloning and targeted gene disruption of $X Y L 1$, a $\beta-1,4-x y l a n a s e$ gene from the 
maize pathogen Cochliobolus carbonum. Mol. Plant-Microbe Interact. 6:467-473.

Apel-Birkhold PC, Walton JD (1996). Cloning, disruption, and expression of two endo- $\beta-1,4$-xylanase genes, $X Y L 2$ and $X Y L 3$, from Cochliobolus carbonum. Appl. Environ. Microbiol. 62:41294135.

Asymeric J-L, Guiseppi A, Pascal M-C, Chippaux M (1988). Mapping and regulation of the cel genes in Erwinia chrysanthemi. Mol. Gen. Genet. 211:95-101.

Crotti LB, Terenzi HF, Jorge JA, de Lourdes M, Polizeli ML (1998) Regulation of pectic enzymes from the exo-1 mutant strain of Neurospora crassa: effects of glucose, galactose, and galacturonic acid. J. Basic Microbiol. 38:181-188.

Hensel M, Holden DW (1996). Molecular genetic approaches for the study of virulence in both pathogenic bacteria and fungi. Microbiology 142:1049-1058.

Kolattukudy PE, Rogers LM, Li D, Hwang CS, Flaishman MA (1995). Surface signaling in pathogenesis. Proc. Natl. Acad. Sci. USA 92:4080-4087.

Mach RL, Strauss J, Zeilinger S, Schindler M, Kubicek CP (1996). Carbon catabolite repression of xylanase I (xyn1) gene expression in Trichoderma reesei. Mol. Microbiol. 21:1273-1281.

Pitkin JW, Panaccione DG, Walton JD (1996). A putative cycle peptide efflux pump encoded by the TOXA gene of the plant pathogenic fungus Cochliobolus carbonum. Microbiology 142:1557-1565.

Ransom RF, Walton JD (1997). Purification and characterization of extracellular $\beta$-xylosidase and $\alpha$-arabinosidase from the plant pathogenic fungus Cochliobolus carbonum. Carbohydr. Res. 297:357-364.
Ronne H (1995). Glucose repression in fungi. Trends genet. 11:12-17. Scott-Craig JS, Cheng YQ, Cervone F, De Lorenzo G, Pitkin JW, Walton JD (1998). Targeted mutants of Cochliobolus carbonum lacking the two major extracellular polygalacturonases. Appl. Environ. Microbiol. 64:1497-1503.

Scott-Craig JS, Panaccione DG, Cervone F, Walton JD (1990). Endopolygalacturonase is not required for pathogenicity of Cochliobolus carbonum on maize. Plant Cell 2:1191-1200.

Tonukari NJ, Scott-Craig JS, Walton JD (2000). The Cochliobolus carbonum SNF1 gene is required for cell wall-degrading enzyme expression and virulence on maize. Plant Cell 12:237-248.

Van Hoof A, Leykam J, Schaeffer HJ, Walton JD (1991). A single $\beta$ 1,3-glucanase secreted by the maize pathogen Cochliobolus carbonum acts by an exolytic mechanism. Physiol. Mol. Plant Pathol. 39:259-267.

Van Wert SL, Yoder OC (1992). Structure of the Cochliobolus heterostrophus glyceraldehyde-3-phosphate dehydrogenase gene. Curr. Genet. 22:29-35.

Walton JD (1994). Deconstructing the cell wall. Plant Physiol 104:1113-1118.

Wegener S, Ransom RF, Walton JD (1999). A unique eukaryotic $\beta$ xylosidase gene from the phytopathogenic fungus Cochliobolus carbonum. Microbiology 145:1089-1095.

Zeilinger S, Mach RL, Schindler M, Herzog P, Kubicek CP (1996) Different inducibility of expression of the two xylanase genes xyn1 and xyn2 in Trichoderma reesei. J. Biol. Chem. 271:25624-25629. 